\title{
Erratum to: The Effects of Organic Matter Amendments on Greenhouse Gas Emissions from a Mitigation Wetland in Virginia's Coastal Plain
}

\author{
R. Scott Winton ${ }^{1}$ - Curtis J. Richardson ${ }^{1}$
}

Published online: 20 August 2015

(C) Society of Wetland Scientists 2015

Erratum to: Wetlands

DOI 10.1007/s13157-015-0674-y

Throughout this manuscript the organic matter loading rates are misreported by a factor of 10 . i.e. 56, 112, 224 and $336 \mathrm{~kg} \mathrm{~m}^{-2}$ should be $5.6,11.2,22.4$ and $33.6 \mathrm{~kg} \mathrm{~m}^{-2}$.

The online version of the original article can be found at http://dx.doi.org/ 10.1007/s13157-015-0674-y.

\section{R. Scott Winton}

scott.winton@gmail.com

Nicholas School of the Environment, Duke University,

Durham, NC 27708, USA 